\title{
Measurements of hydrodynamics, sediment, morphology and benthos on Ameland ebb-tidal delta and lower shoreface
}

\author{
Bram C. van Prooijen ${ }^{1}$, Marion F. S. Tissier ${ }^{1}$, Floris P. de Wit ${ }^{1}$, Stuart G. Pearson ${ }^{1,3}$, \\ Laura B. Brakenhoff ${ }^{2}$, Marcel C. G. van Maarseveen ${ }^{2}$, Maarten van der Vegt $^{2}$, Jan-Willem $\mathbf{M o l}^{6}$, \\ Frank Kok ${ }^{6}$, Harriette Holzhauer ${ }^{4,3}$, Jebbe J. van der Werf ${ }^{3,4}$, Tommer Vermaas ${ }^{3}$, Matthijs Gawehn ${ }^{3}$, \\ Bart Grasmeijer $^{3}$, Edwin P. L. Elias ${ }^{3}$, Pieter Koen Tonnon ${ }^{3}$, Giorgio Santinelli ${ }^{3}$, José A. A. Antolínez ${ }^{1}$, \\ Paul Lodewijk M. de Vet ${ }^{1,3}$, Ad J. H. M. Reniers ${ }^{1}$, Zheng Bing Wang ${ }^{1,3}$, Cornelis den Heijer ${ }^{1,5}$, \\ Carola van Gelder-Maas ${ }^{6}$, Rinse J. A. Wilmink ${ }^{6}$, Cor A. Schipper ${ }^{6}$, and Harry de Looff ${ }^{6}$ \\ ${ }^{1}$ Department of Hydraulic Engineering, Delft University of Technology, Delft, the Netherlands \\ ${ }^{2}$ Department of Physical Geography, Utrecht University, Utrecht, the Netherlands \\ ${ }^{3}$ Deltares, Delft, the Netherlands \\ ${ }^{4}$ Department of Water Engineering and Management, University of Twente, Enschede, the Netherlands \\ ${ }^{5}$ Data2day, Delft, the Netherlands \\ ${ }^{6}$ Rijkswaterstaat, Lelystad, the Netherlands \\ Correspondence: Bram C. van Prooijen (b.c.vanprooijen@tudelft.nl)
}

Received: 21 January 2020 - Discussion started: 18 February 2020

Revised: 10 September 2020 - Accepted: 6 October 2020 - Published: 14 November 2020

Abstract. A large-scale field campaign was carried out on the ebb-tidal delta (ETD) of Ameland Inlet, a basin of the Wadden Sea in the Netherlands, as well as on three transects along the Dutch lower shoreface. The data have been obtained over the years 2017-2018. The most intensive campaign at the ETD of Ameland Inlet was in September 2017.

With this campaign, as part of KustGenese2.0 (Coastal Genesis 2.0) and SEAWAD, we aim to gain new knowledge on the processes driving sediment transport and benthic species distribution in such a dynamic environment. These new insights will ultimately help the development of optimal strategies to nourish the Dutch coastal zone in order to prevent coastal erosion and keep up with sea level rise. The dataset obtained from the field campaign consists of (i) single- and multi-beam bathymetry; (ii) pressure, water velocity, wave statistics, turbidity, conductivity, temperature, and bedform morphology on the shoal; (iii) pressure and velocity at six back-barrier locations; (iv) bed composition and macrobenthic species from box cores and vibrocores; (v) discharge measurements through the inlet; (vi) depth and velocity from X-band radar; and (vii) meteorological data.

The combination of all these measurements at the same time makes this dataset unique and enables us to investigate the interactions between sediment transport, hydrodynamics, morphology and the benthic ecosystem in more detail. The data provide opportunities to calibrate numerical models to a high level of detail. Furthermore, the open-source datasets can be used for system comparison studies.

The data are publicly available at 4TU Centre for Research Data at https://doi.org/10.4121/collection:seawad (Delft University of Technology et al., 2019) and https://doi.org/10.4121/collection:kustgenese2 (Rijkswaterstaat and Deltares, 2019). The datasets are published in netCDF format and follow conventions for CF (Climate and Forecast) metadata. The http://data.4tu.nl (last access: 11 November 2020) site provides keyword searching options and maps with the geographical position of the data. 


\section{Introduction}

Systems of barrier islands and associated tidal inlets are found along a major part of the world's coastlines (Glaeser, 1978; Stutz and Pilkey, 2011). The sheltered back-barrier basins have been attractive for human settlement and all kinds of recreational and economic activities. The inlet systems form unique landscapes with channels, shoals and salt marshes, providing valuable habitats for numerous marine species and birds. Over the last decades, these systems have been under increasing pressure due to economic activities, while also the awareness of the uniqueness of the areas has been recognized and formalized. For example, the Wadden Sea (the Netherlands, Germany and Denmark) was identified as a World Heritage Site in 2009 for its unique geological and ecological value. Accounting for all the functions and values of the system requires a careful sustainable management strategy. This is even more necessary in view of the foreseen climate change. Relative sea level rise threatens these systems in various ways. The higher water level reduces the safety level of the barrier islands, while the intertidal flats in the basins might risk drowning if they do not keep pace with rising waters (Wang et al., 2018).

To keep the safety standards for the Dutch coast, the coastal zone is being nourished. The strategy is to let the sediment volume in the coastal zone (as defined in Fig. 1) keep pace with sea level rise (Mulder et al., 2011). The coastal zone may however lose sediment over the offshore boundary (approximately the depth contour mean sea level $-20 \mathrm{~m}$ ) and through the inlets towards the Wadden Sea. Quantifying these fluxes is not trivial (Van Rijn, 1997). The net fluxes into the Wadden Sea depend on subtle variations in the large flood and ebb fluxes (Gatto et al., 2017). Furthermore the dynamics of the ebb tidal delta make predictions complicated. The flux over the offshore boundary at the lower shoreface is complicated by the episodic nature of the sediment transport at this depth.

Numerous conceptual models have been formulated to explain sediment dynamics and interactions at barrier island type inlets (see a recent summary by Hayes and FitzGerald, 2013). These conceptual descriptions provide a general understanding of the factors controlling the shape, size and general characteristics of a tidal inlet and its associated ebbtidal delta. The size of the inlet is primarily controlled by the tidal prism (e.g. Jarrett, 1976), while the ratio between wave and tidal energy controls the geometry of the barrier islands, the inlet gorge and the ebb-tidal delta. Such a conceptual understanding of large-scale behaviour is a crucial first step. However, a more detailed and quantitative description is required to answer current predictive needs. Furthermore, these conceptual models often lack a description of the underlying physical processes. Knowledge on these processes is essential if one aims to understand changes on smaller scales,

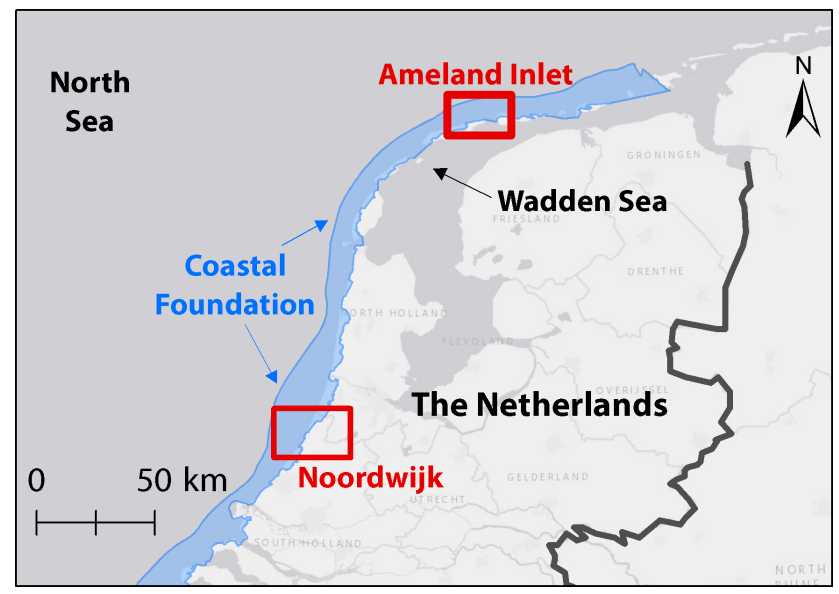

Figure 1. Location of Ameland Inlet and the Wadden Sea within the Netherlands. Basemap sources: Esri, HERE, Garmin, (C) OpenStreetMap contributors. Distributed under a Creative Commons BYSA License and the GIS user community.

where human intervention may influence the behaviour such that it cannot be accurately described by existing concepts and equilibrium relationships. However, process-based models require accurate and high-resolution data for calibration and validation. Suitable field datasets that comprise sufficient and coherent observations of hydrodynamics, sediment transport and morphological change are scarce, as tidal inlets are notoriously challenging and expensive places to collect field data.

The Dutch Government Rijkswaterstaat therefore started the KustGenese2.0 research programme in collaboration with Deltares. Part of this programme was an extensive field campaign at the Ameland Inlet, the Netherlands (Fig. 1), in close collaboration with the universities of Delft, Utrecht and Twente, via the SEAWAD project. Hydrodynamics, turbidity, sediment composition and benthic species distribution were measured at various locations on the ebb-tidal delta, in the inlet gorge and in the basin. Additionally, measurements were carried out at the Holland coast, near Noordwijk. These datasets help us to (1) improve our understanding of the physical processes underlying mixed-energy tidal inlets, (2) formulate new algorithms describing these physics, and (3) evaluate the skill of process-based numerical models, and if necessary improve the underlying model formulations. Ultimately, the obtained insights and improved models will lead to more efficient and effective management of the barrier island system of the Wadden Sea to prevent coastal erosion and keep up with sea level rise.

This paper describes the datasets obtained in 2017 and 2018. The dataset is accessible via https://doi.org/10.4121/collection:seawad and https://doi.org/10.4121/collection:kustgenese2. The reposi- 
tories include the raw and processed data as well as relevant metadata and processing scripts.

\section{Area description}

The Wadden Sea (Fig. 1) consists of a series of 33 tidal inlet systems and in total extends over a distance of nearly $500 \mathrm{~km}$ along the northern part of the Netherlands (West Frisian Islands) and the North Sea coasts of Germany and Denmark (the East and North Frisian Islands). The tidal basins consist of extensive intertidal areas and tidal channels that support a wide variety of marine mammals, birds and fish. This unique natural habitat was selected as a World Heritage Site in 2009. Ameland Inlet is centrally located in the Dutch part of the Wadden Sea, bordered by the islands Terschelling to the west and Ameland to the east (Fig. 1). The associated Ameland tidal basin has a length of about $30 \mathrm{~km}$ and covers an area of around $309 \mathrm{~km}^{2}$. With a tidal range of approximately $2 \mathrm{~m}$ and a moderate wave climate, the inlet can be classified as meso-tidal and mixed-energy (Hayes, 1975; Davis and Hayes, 1984).

Ameland Inlet is considered to be relatively undisturbed as no major ongoing human interferences or interventions in the past directly impact the natural processes. However, Elias et al. (2012) point out that natural processes in the Wadden Sea can only reign free within its established boundaries. Over the last centuries, multiple large- and small-scale interventions, such as coastal defence works, closure dams, dikes, sea walls, land reclamations and closing of the Middelzee around 1600, have reduced and essentially fixed the basin dimensions and kept the barrier islands in place. As a result, a geomorphic transition in morphodynamic behaviour of Ameland Inlet occurred around 1926 as the main ebb channel migrated from an updrift to a downdrift position in the inlet gorge, encroaching on the western side of Ameland (Elias et al., 2019). This channel has retained this position since then, partly due to extensive coastal protection works at the tip of the island. Within this context, natural processes can reshape the individual shoals and channels on the ebb-tidal delta, without human interference.

\section{Instrumentation}

\subsection{Frames}

Five frames were built and equipped with acoustic Doppler velocimeters (ADVs), an upward-looking acoustic Doppler current profiler (ADCP), a downward-looking high-resolution ADCP, optical backscatter sensors (OBSs), a laser in situ scattering and transmissometer (LISST) sensor, a sonar and a multi-parameter probe (MPP). The exact configuration slightly differs per frame. As an example, Fig. 4 and Table 1 describe the configuration for Frame 4.

The procedure for determining the offset of the compass was to rotate the mounting frame annotating every $10^{\circ}$ the device heading angle (compass heading) and the true angle measured with high-accuracy GPS (magnetic heading) not affected by the frame. This was repeated in reverse direction. An averaged compass deviation (from the two cycles) at a $10^{\circ}$ interval was taken for the compass calibration.

High-frequency measurements offer possibilities to analyse intra-wave processes and turbulence characteristics. The ADV sampled with a frequency of $16 \mathrm{~Hz}$ (Nortek Vector) or $10 \mathrm{~Hz}$ (Sontek Hydra) in almost continuous mode: 29 min bursts were measured at an interval of $30 \mathrm{~min}$. The instruments measured the distance to the bed level at the beginning and end of the bursts, providing time series of the bed level every $30 \mathrm{~min}$. Generally, at least two ADVs were placed near the seabed to analyse flow properties at different heights (ranging from 0.35 to $1.00 \mathrm{~m}$ above the bed).

The velocity profile over the full water column was measured to determine the tidal flow and wave orbital motion. The upward-looking ADCP (Teledyne RDI Workhorse Monitor) measured with a frequency of $1.25 \mathrm{~Hz}$ with bursts of $30 \mathrm{~min}$ at intervals of 30 or $60 \mathrm{~min}$. The cell sizes differed for the various deployment locations: $0.25,0.50,0.80$ or $1 \mathrm{~m}$. The number of cells was always sufficient to cover the full water column above the instrument.

To measure the near-bed profile, including the wave orbital motions, a high-resolution ADCP was deployed. The downward-looking ADCP (Nortek Aquadopp HR) measured with $4 \mathrm{~Hz}$ in near-continuous mode: 29 min bursts were measured over an interval of $30 \mathrm{~min}$. The cell size was set to $0.03 \mathrm{~m}$ for 13 cells, providing a maximum representative profile height of $0.39 \mathrm{~m}$.

Turbidity was measured to determine the sediment concentration. Four OBSs (Campbell OBS-3+ Turbidity Sensor) were attached to a leg of each frame, close to the bed $(0.1-$ $0.8 \mathrm{~m}$ ). They were each connected to an ADV and measured with the same frequency, burst interval and period. A calibration was carried out at the laboratory of Utrecht University. Sediment (mainly sand) from the seabed was taken and mixed up in a mixing tank. The sediment concentration was slowly increased, obtaining the relation between voltage and sediment concentration. As the suspended sediment in the field also contained fine sediments, the results from the laboratory (containing sand) cannot be translated directly into a mass concentration (Pearson et al., 2019). Therefore, only the raw voltage output is provided.

A LISST (LISST-100X particle size analysers, Sequoia) uses the scattering and transmission of a laser to analyse the suspended particle size distribution at a point $0.6 \mathrm{~m}$ above the bed. Every $60 \mathrm{~s}$, there is a $15 \mathrm{~s}$ continuous burst of measurements at $1 \mathrm{~Hz}$. The instrument can distinguish particles within a range of $2.5-500 \mu \mathrm{m}$.

The $3 D$ sonar measures the detailed bed morphology and can be used to detect small-scale bedforms like ripples. The 3D sonar (Marine Electronics type 2001) was mounted approximately $1 \mathrm{~m}$ above the bed. It measured with intervals of $1 \mathrm{~h}$ by rotating around its own axis and scanning 200 swaths 


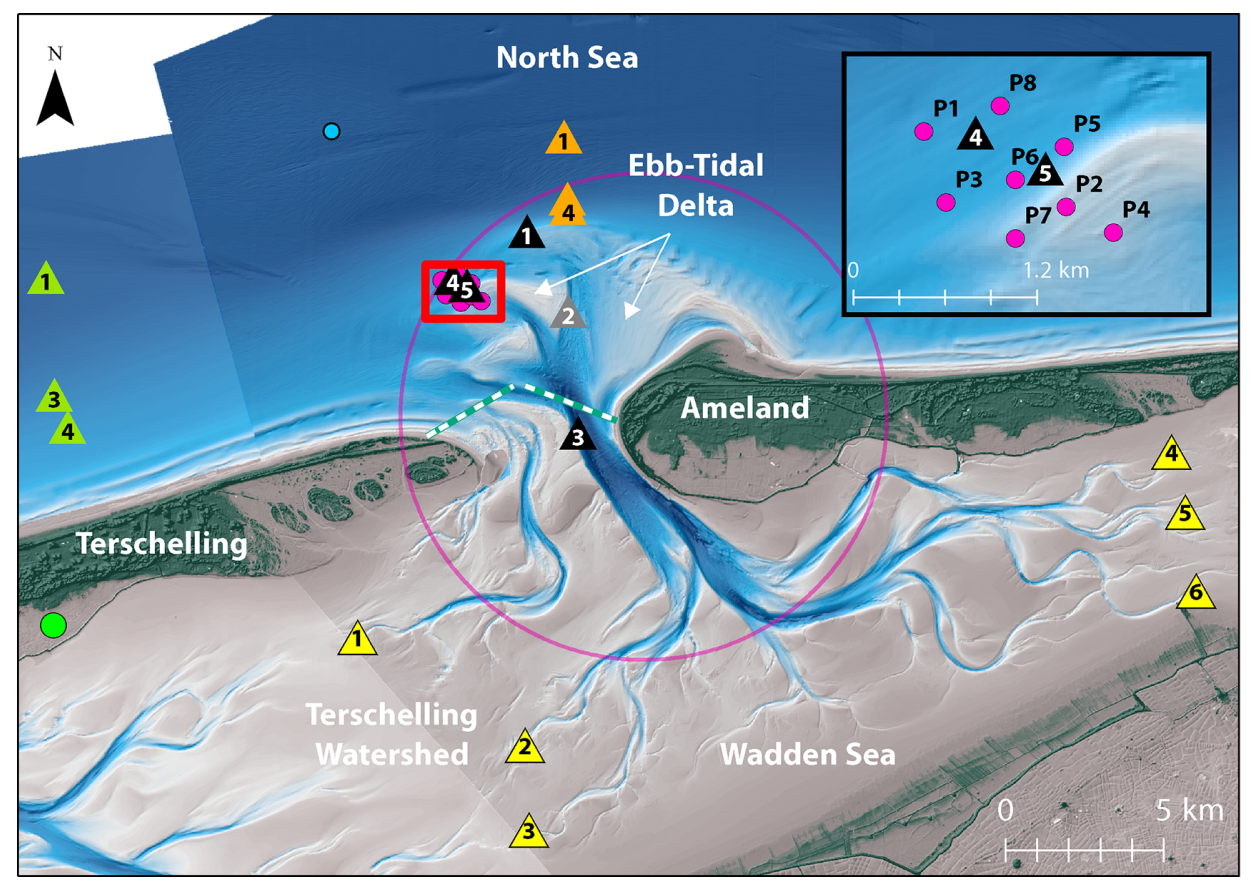

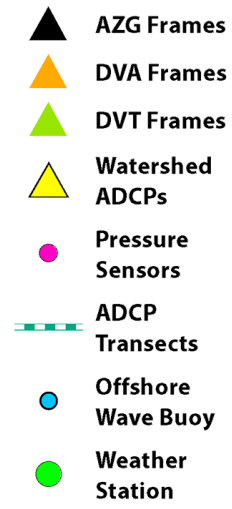

Bed Elevation

$[\mathrm{m}]$

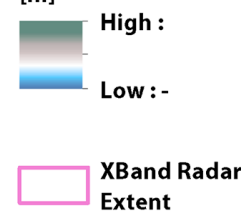

Figure 2. Locations of hydrodynamic, sediment and atmospheric measurements carried out during the 2017 campaigns. AZG: Amelander Zeegat or Ameland Inlet; DVA: Diepere Vooroever Ameland or lower shoreface Ameland; DVT: Diepere Vooroever Terschelling or lower shoreface Terschelling. Bathymetry source: Rijkswaterstaat Vaklodingen. Elevation source: Actueel Hoogtebestand Nederland (AHN), Rijkswaterstaat.
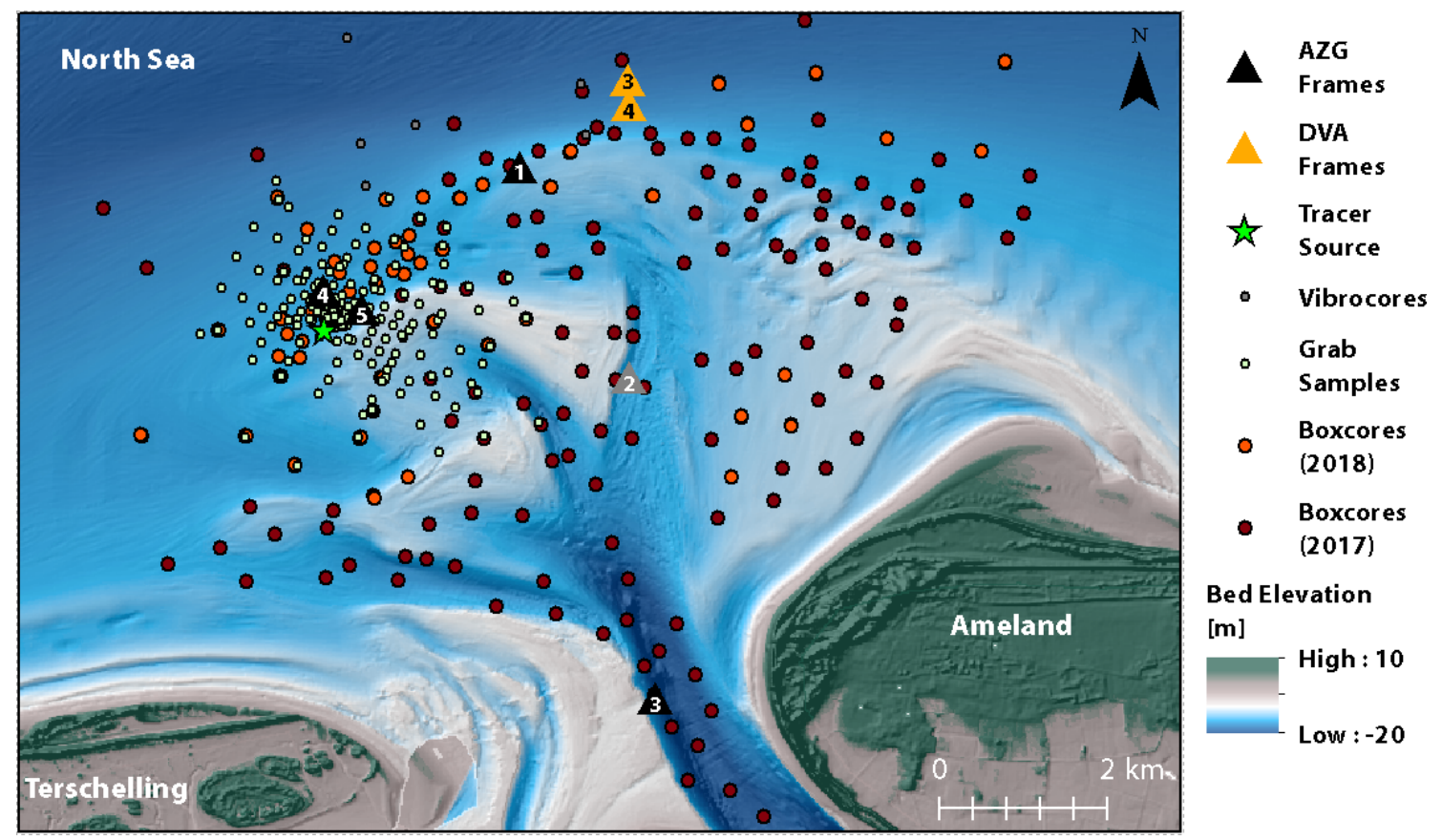

Bed Elevation

[m]

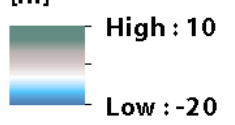

Figure 3. Locations of seabed sediment samples taken in September and October 2017, including box cores, van Veen grab samples and vibrocores. The source location for the sediment tracer study is indicated with a green star. Measurement frames from the AZG (Ameland Inlet) and DVA (Ameland Foreshore) campaigns are shown as triangles for context. Bathymetry source: Rijkswaterstaat Vaklodingen. Elevation source: Actueel Hoogtebestand Nederland (AHN), Rijkswaterstaat. 


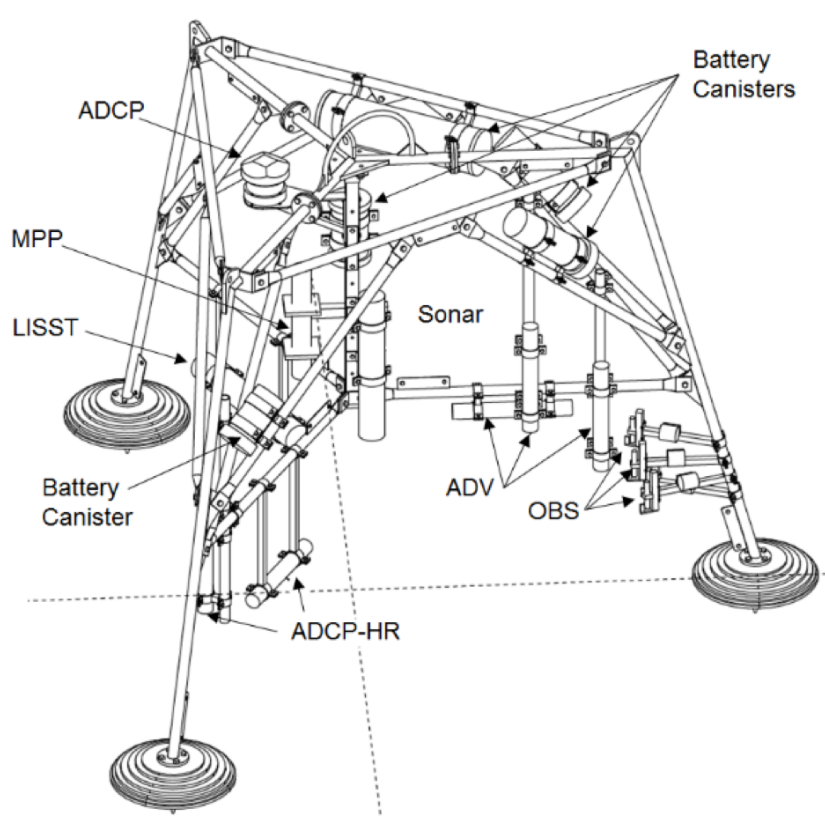

Figure 4. Configuration of the instruments on one of the $2.4 \mathrm{~m}$ high frames (Frame 4). See main text for an explanation of each instrument and Table 1 for a summary of the instruments' settings.

of the bed in a $360^{\circ}$ circle; thus all swaths are $0.9^{\circ}$ apart. The maximum deviation of the sonar beam with the vertical was $75^{\circ}$, and the resolution within the swaths was $0.9^{\circ}$. The horizontal resolution is highest right below the sonar head $(1.6 \mathrm{~cm})$ and decreases to $22 \mathrm{~cm}$ at the edges of the swath ( $>3.5 \mathrm{~m}$ away from the centre of the image). The vertical resolution is approximately $4.5 \mathrm{~mm}$.

The multi-parameter probe (MPP) measures pressure, temperature, conductivity, $\mathrm{pH}$, turbidity, chlorophyll, bluegreen algae phycocyanin and optical dissolved oxygen with a frequency of $1 \mathrm{~Hz}$ and was mounted $1.3 \mathrm{~m}$ above the seabed. These data can be used to calculate salinity and density and to analyse the interaction between physical and biogeochemical processes. The turbidity (in NTU: nephelometric turbidity unit) was a direct output of the multiprobe, applying a relation between the measured voltage and turbidity, provided by the manufacturer.

\subsection{Wave measurements}

Offshore wave conditions were measured by a Datawell Directional Waverider Mk3 (indicated by the light blue dot in Fig. 2). It provides half hourly estimates of spectral wave characteristics (including significant wave height, mean and peak period, and mean direction) during the field campaign.

To further characterize the spatial variability in wave characteristics at the Ameland ebb-tidal delta, eight additional pressure sensors (Ocean Sensor Systems, Inc.) were installed $25-50 \mathrm{~cm}$ above the seabed around Frames 4 and 5 (P1-P8; see magenta dots in Fig. 2); $10 \mathrm{~Hz}$ continuous pressure data were successfully retrieved from seven of these instruments (all but P6). These pressure signals were subsequently corrected for variations in the atmospheric pressure (see also Sect. 3.1). They can be used to characterize mean water level and wave statistics at the ebb-tidal delta, as well as also intrawave properties.

\subsection{Discharge and velocity measurements}

Transect measurements were carried out at two transects in the opening between the islands Terschelling and Ameland (see dashed lines in Fig. 2). The velocities in the full cross section were measured by research vessels equipped with a downward-looking ADCP moving along the transect over a period of at least $13 \mathrm{~h}$ to cover a full tidal cycle. Water samples were taken during the measurements, in order to convert backscatter to suspended particulate matter concentrations later on.

Flow measurements were carried out at the end of the tidal channels in the back-barrier basins, close to the border with the adjacent basin (see Fig. 2). These borders are referred to as tidal divides (van Veen et al., 2005). These locations are chosen to determine the flow between the between the basins. At each tidal divide, three upward-looking ADCPs (Nortek Aquadopp LR) were placed (see yellow triangles in Fig. 2). These measured with an interval of $1 \mathrm{~min}$. The cell size was set to $0.10 \mathrm{~m}$ for 45 cells. This implies that the full water column was always covered.

The measurements in the opening and at the tidal divides can be used to analyse the water budgets of the Ameland Basin.

\subsection{Bathymetry}

Half-yearly bathymetric surveys of the ebb-tidal delta were conducted between 2016 and 2019. These datasets are an addition to the regular bathymetric monitoring conducted here and follow similar protocols. Ameland Inlet has a long history of bathymetric surveying (Elias et al., 2019). Since 1985, bathymetric data have been collected systematically by Rijkswaterstaat, which is part of the Ministry of Public Works and Infrastructure, following the Vaklodingen protocol (De Kruif, 2001). More specifically, the ebb-tidal delta is measured with approximately $200 \mathrm{~m}$ transect spacing using a single-beam echo sounder. Following quality checks for measurement errors, data are reduced to $1 \mathrm{~m}$ transect resolution, combined with nearshore coastline measurements and lidar data for the tidal flats in the basin, and interpolated to $20 \mathrm{~m} \times 20 \mathrm{~m}$ grids. The grids are stored digitally as $10 \mathrm{~km} \times 12.5 \mathrm{~km}$ blocks called Vaklodingen.

In addition to the ebb-delta scale maps, detailed multibeam echo-sounding surveys were conducted at four focus areas at several intervals. The raw data were cleaned for data outliers, sub-gridded to $1 \mathrm{~m}$ resolution and mosaicked in single datasets. The high-resolution renderings allow us to vi- 
Table 1. Instrumentation for Frame 4 during the AZG deployment. The number of instruments and their settings varied by frame and by deployment. For a complete overview, see repository.

\begin{tabular}{lll}
\hline & \multicolumn{2}{c}{ Frame 4, 29 August 2017-9 October 2017} \\
\hline Instrument & Height above bed & Settings \\
\hline Upward ADCP & $2.30 \mathrm{~m}$ & 30 min bursts every $60 \mathrm{~min}$, bin size $0.25 \mathrm{~m}, 1.25 \mathrm{~Hz}$ \\
Downward ADCP & $0.52 \mathrm{~m}$ & 29 min bursts every $30 \mathrm{~min}$, bin size $0.03 \mathrm{~m}, 4 \mathrm{~Hz}$ \\
Low ADV & $0.36 \mathrm{~m}$ & 29 min bursts every $30 \mathrm{~min}, 16 \mathrm{~Hz}$ \\
Mid. ADV & $0.65 \mathrm{~m}$ & 29 min bursts every $30 \mathrm{~min}, 16 \mathrm{~Hz}$ \\
High ADV & $0.93 \mathrm{~m}$ & 29 min bursts every $30 \mathrm{~min}, 16 \mathrm{~Hz}$ \\
Low OBS & $0.19 \mathrm{~m}$ & 29 min bursts every $30 \mathrm{~min}, 16 \mathrm{~Hz}$ \\
Middle OBS & $0.30 \mathrm{~m}$ & 29 min bursts every $30 \mathrm{~min}, 16 \mathrm{~Hz}$ \\
High OBS & $0.50 \mathrm{~m}$ & 29 min bursts every $30 \mathrm{~min}, 16 \mathrm{~Hz}$ \\
Highest OBS & $0.79 \mathrm{~m}$ & 29 min bursts every $30 \mathrm{~min}, 16 \mathrm{~Hz}$ \\
LISST & $0.60 \mathrm{~m}$ & $15 \mathrm{~s}$ bursts every $60 \mathrm{~s}, 1 \mathrm{~Hz}$ \\
MPP & $1.27 \mathrm{~m}$ & 1 sample every 5 min \\
Sonar & $0.98 \mathrm{~m}$ & $13 \mathrm{D}$ image every hour \\
\hline
\end{tabular}

sualize and analyse bedforms characteristics such as height, asymmetry and migration. Assuming that the bedforms are still active and governed by present-day hydrodynamic conditions, the bedform distribution, arrangement and morphology provide information about the locally dominant bottom currents and sediment transport (Boothroyd, 1985; Fraccascia et al., 2016).

The navigational X-band radar (Terma Scanter 2000 with $\mathrm{VV}$ polarization) on the lighthouse of Ameland was used as a remote sensing tool to estimate depths and currents in the outer delta. The area that is captured by the radar covers a circle with a radius of approximately $7.5 \mathrm{~km}$ (see Fig. 1). Video fragments of $12 \mathrm{~min}$ were stored every $20 \mathrm{~min}$, with a frame rate of 1 image per $2.85 \mathrm{~s}$.

\subsection{Seabed composition and benthos}

Bed samples were taken with a Reineck box corer $\left(0.078 \mathrm{~m}^{2}\right)$. A map of the sampling locations is shown in Fig. 3. Sediment samples were taken from the top $8 \mathrm{~cm}$ of the box core and analysed with a Malvern Mastersizer resulting in a sediment distribution with 67 bins, ranging from 0.01 to $2000 \mu \mathrm{m}$. After sieving over a $1 \mathrm{~mm}$ sieve, macrobenthic species were conserved and analysed in the laboratory. Additionally, samples were taken with a square box core to create lacquer peals of selected cores. Samples with a $6 \mathrm{~m}$ vibrocore were taken at the lower shoreface. Finally, a van Veen grab sampler was used to sample the seabed to a depth of $5 \mathrm{~cm}$ from the surface at 187 locations. The grain sizes of these samples were also determined with the Malvern Mastersizer.

\section{Deployments}

The majority of the measurements were carried out in the period from 29 August until 10 October 2017 during the so-called Ameland Inlet (AZG) campaign. This was the period when the five frames and the eight stand-alone pressure sensors were deployed at the Ameland ebb-tidal delta, the velocity transects were measured, the multibeam measurements were carried out, and the sediment samples (box cores and grabs) were taken. The frame measurements covered a period of $40 \mathrm{~d}$ (see Fig. 4). The frames were serviced after 3 weeks and redeployed at the same location. Except for one bent ADV stem, all instruments were intact. At the end of the period, four frames were retrieved without damage of instruments (Frames 1, 3, 4 and 5). Data have been retrieved for all instruments. The LISST on Frame 5 did not work properly, and no usable data were obtained. Frame 2 (see grey triangle in Fig. 2) was covered with sand after a storm, due to migration of the channel bank. As of this writing, it has not yet been retrieved.

Three of the frames (Frames 1, 3 and 4) were then redeployed in the period 8 November 2017 till 11 December 2017 on a transect perpendicular to Ameland (DVA frames; Fig. 2). These three frames were finally re-deployed in the periods 11 January 2018 till 6 February 2018 and 12 March 2018 till 26 March 2018 on a transect perpendicular to Terschelling (DVT frames; Fig. 2). Finally, the frames were deployed offshore Noordwijk (Fig. 1) from 4 April 2018 to 15 May 2018. An overview of the deployments of the frames is provided in Table 2. Sediment composition and macrobenthic species were sampled in two surveys. During the first survey, 4-6 September 2017 and 2021 September 2017, 166 samples were collected. The second survey with 55 samples took place on 24 March 2018.

\section{Data processing}

The ADV and ADCP data were processed in two steps. In the first step, the correlation and signal-to-noise ratio (SNR) 
Table 2. Overview of the measurement periods and positions of the frames. The campaigns are referred to as AZG (Amelander Zeegat in Dutch): Amelander Inlet; DVA (Diepe Vooroever Ameland): lower shoreface Ameland; DVT1 (Diepe Vooroever Terschelling 1): lower shoreface Terschelling 1; DVT2 (Diepe Vooroever Terschelling 2): lower shoreface Terschelling 2; and DVN (Diepe Vooroever Noordwijk): lower shoreface Noordwijk.

\begin{tabular}{|c|c|c|c|c|c|c|}
\hline Campaign & Frame & Begin time & End time & Lat. & Long. & Approx. depth \\
\hline \multirow{5}{*}{ AZG } & 1 & 30 Aug 2017, 10:11 & 9 Oct $2017,15: 20$ & $53.50^{\circ}$ & $5.57^{\circ}$ & $7 \mathrm{~m}$ \\
\hline & 2 & 30 Aug $2017,16: 38$ & not retrieved & $53.48^{\circ}$ & $5.59^{\circ}$ & $9 \mathrm{~m}$ \\
\hline & 3 & 30 Aug $2017,15: 37$ & 10 Oct $2017,07: 10$ & $53.44^{\circ}$ & $5.59^{\circ}$ & $15 \mathrm{~m}$ \\
\hline & 4 & 29 Aug $2017,15: 55$ & 9 Oct $2017,15: 50$ & $53.49^{\circ}$ & $5.54^{\circ}$ & $9 \mathrm{~m}$ \\
\hline & 5 & 29 Aug $2017,15: 28$ & 9 Oct $2017,16: 45$ & $53.49^{\circ}$ & $5.54^{\circ}$ & $7 \mathrm{~m}$ \\
\hline \multirow{3}{*}{ DVA } & 1 & 8 Nov $2017,13: 00$ & 11 Dec $2017,13: 15$ & $53.53^{\circ}$ & $5.59^{\circ}$ & $20 \mathrm{~m}$ \\
\hline & 3 & 8 Nov $2017,11: 00$ & 11 Dec $2017,14: 15$ & $53.51^{\circ}$ & $5.59^{\circ}$ & $16 \mathrm{~m}$ \\
\hline & 4 & 8 Nov $2017,10: 30$ & 11 Dec 2017, 15:00 & $53.51^{\circ}$ & $5.59^{\circ}$ & $10 \mathrm{~m}$ \\
\hline \multirow{3}{*}{ DVT1 } & 1 & 11 Jan $2018,12: 20$ & 6 Feb 2018, 09:30 & $53.49^{\circ}$ & $5.34^{\circ}$ & $20 \mathrm{~m}$ \\
\hline & 3 & 11 Jan $2018,14: 00$ & 6 Feb $2018,10: 30$ & $53.45^{\circ}$ & $5.35^{\circ}$ & $14 \mathrm{~m}$ \\
\hline & 4 & 11 Jan $2018,15: 15$ & 6 Feb 2018, 11:30 & $53.45^{\circ}$ & $5.35^{\circ}$ & $10 \mathrm{~m}$ \\
\hline \multirow{3}{*}{ DVT2 } & 1 & 12 Mar 2018, 16:00 & $26 \operatorname{Mar} 2018,10: 10$ & $53.49^{\circ}$ & $5.34^{\circ}$ & $20 \mathrm{~m}$ \\
\hline & 3 & 12 Mar 2018, 19:50 & $26 \operatorname{Mar} 2018,13: 40$ & $53.45^{\circ}$ & $5.35^{\circ}$ & $14 \mathrm{~m}$ \\
\hline & 4 & $12 \operatorname{Mar} 2018,17: 50$ & $26 \operatorname{Mar} 2018,12: 40$ & $53.45^{\circ}$ & $5.35^{\circ}$ & $10 \mathrm{~m}$ \\
\hline \multirow{3}{*}{ DVN } & 1 & 4 Apr $2018,12: 15$ & 15 May $2018,13: 30$ & $52.28^{\circ}$ & $4.24^{\circ}$ & $20 \mathrm{~m}$ \\
\hline & 3 & 4 Apr $2018,14: 10$ & 15 May $2018,17: 00$ & $52.23^{\circ}$ & $4.39^{\circ}$ & $12 \mathrm{~m}$ \\
\hline & 4 & 4 Apr $2018,13: 40$ & 15 May $2018,14: 50$ & $52.24^{\circ}$ & $4.37^{\circ}$ & $16 \mathrm{~m}$ \\
\hline
\end{tabular}

were determined. Threshold values for correlation and SNR were based on Elgar et al. (2005). Secondly, velocities were despiked by using the 3D phase space method (Goring and Nikora, 2002; Mori et al., 2007), in which velocities and their first- and second-order derivatives are plotted in a 3D space. Subsequently, points outside a given ellipsoid are excluded. The flagged data are replaced by NaNs (not a number). Positioning and orientation of the instruments was based on a laser scan of the frame and the calibration of the compasses.

To calibrate the LISST, the background scatter intensity of the laser in clean water must be measured. This procedure was carried out prior to each campaign in accordance with the manufacturer's specifications. This calibration stage ensures that the laser detection rings are properly aligned and provides a basis for interpreting the measurements on-site. Upon retrieval of the data from the instrument, the raw data were processed using the LISST-SOP Version 5.0.50 software. No despiking or filtering was carried out on the time series.

Pressure signals are measured by the ADVs, ADCPs, Aquadopps, LISST, multi-parameter probe and stand-alone pressure sensors. The pressure sensors measure the total pressure, which is the combination of atmospheric pressure and water pressure. To obtain the water pressure, the total pressure is reduced by the air pressure. The air pressure is obtained from the nearest weather station (Terschelling Hoorn AWS) of the Royal Netherlands Meteorological Institute (KNMI).
The point clouds of each sonar scan were interpolated on a regular grid with a $0.01 \mathrm{~m}$ step size using a second-order LOESS interpolator, following Ruessink et al. (2015). This interpolator also removes spikes. Because of the low resolution at the edges, the grids run from -2.5 to $2.5 \mathrm{~m}$ in both $x$ and $y$ directions. The mean distance to the sonar head was removed from the depth values, so larger bed level variations through time are not visible anymore. The sonar does not store its own heading, so all images were rotated to the NE-S-W scheme using the rotation angles of the other instruments. Data quality was checked for each image. A flag of " -1 " was assigned to data that should be treated with caution (e.g. if the amount of sediment suspension was too high for the sonar to detect the bed). Data with good quality were assigned a flag " 1 ".

The vibrocores were subdivided in $1 \mathrm{~m}$ parts on board and further processed in the lab. The cores were opened and photographed, and a lithostratigraphic description of the cores was made following the "standard core description method" of the Dutch Geological Survey (Bosch et al., 2000).

Depths and currents were also estimated from the radar data using a depth-inversion algorithm called XMFit (X-band MATLAB Fitting; see Friedman, 2013). This algorithm is based on the fitting of the wave linear dispersion relationship on the radar-derived image intensity dispersion shell in the wave number-frequency space. The accuracy depends on the distance from the lighthouse. The system returned 1 to 3 

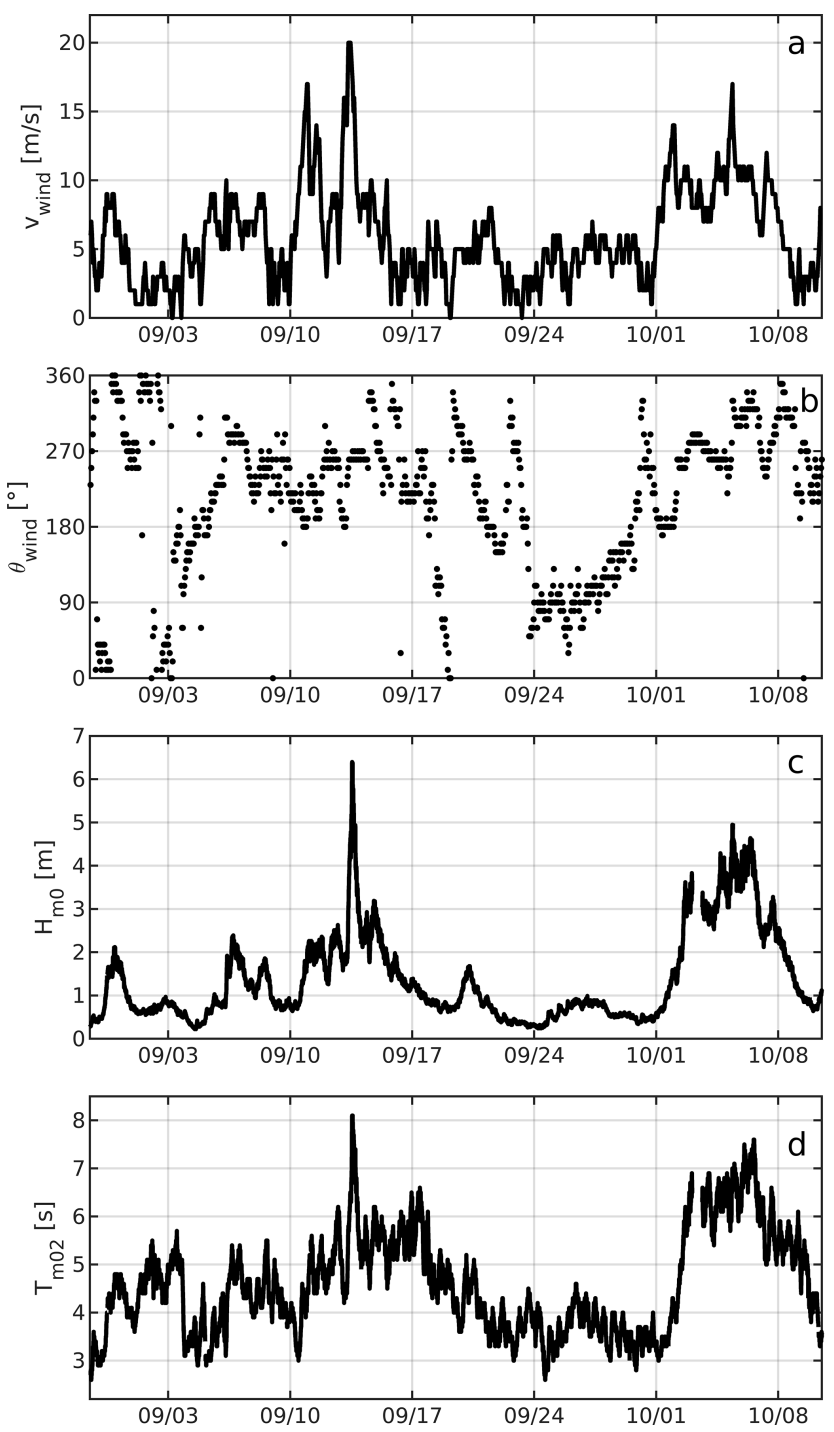

Figure 5. Environmental conditions for the first measurement period (29 August 2017 till 10 October 2017). Wind speed (a) and direction (b) measured at KNMI location 251 Hoorn Terschelling (green dot in Fig. 2); offshore significant wave height $H_{\mathrm{S}}$ (c) and mean spectral period $T_{\mathrm{m} 02}$ (d) measured by wave buoy AZG-B11 (blue dot in Fig. 2).

depth and surface current estimates per hour depending on the quality of the radar backscatter.

\section{Environmental conditions}

\subsection{Hydrodynamics}

The wind speed and direction as well as the offshore significant wave height and mean spectral period are shown in Fig. 5 for the first part of the field campaign. During this part of the campaign, two storms occurred: Aileen/Sebastian (1113 September) and Xavier (3-5 October). A wind speed up till $20 \mathrm{~m} \mathrm{~s}^{-1}$ (13 September) was measured during Sebastian.
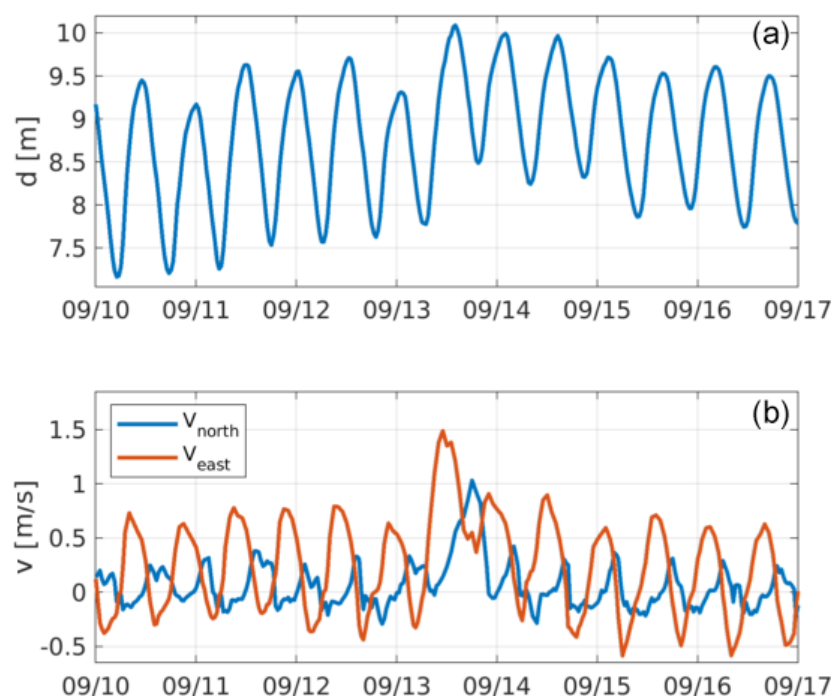

Figure 6. Results from Frame 4 for the period 10 September 2017 till 17 September 2017. (a) Mean water depth; (b) depth-averaged mean flow velocity estimated from the upward-looking ADCPs.

A calm weather period (wind speed $<8 \mathrm{~m} \mathrm{~s}^{-1}$ ) was present during 16-29 September. During the other deployment periods, several storms were captured as well, like the one on 18 January. The high wind speed on 13 September resulted in significant water level set-up (Fig. 6a) and significant windinduced flows (Fig. 6b) at the ebb-tidal shoal (Frame 4). This shallow area with a relatively steep bed slope is very sensitive to meteorological conditions: there is a strong interaction between tidal flow, wind- and wave-driven flow, and waves. This makes the location suitable for analysis of these types of hydrodynamic interactions. The flow velocity at Frame 3 (not shown) is significantly different, as it is located on the side of the deep inlet channel. Wave-induced currents are of minor importance, and the flow is highly tide dominant at this location. Storm surges on the North Sea do lead to variations in water level and discharge through the inlet, but the variation due to spring-neap tide variations is more significant. Inside the basin, the wind does have a stronger effect again. Especially storms from the southwest (the dominant wind direction) lead to increased flow velocities on the tidal divides inside the basin. During various periods of southwestern wind, the flow is dominated by the wind, leading to unidirectional flow over a full tide; that is, the tidal forcing is not strong enough to reverse the flow.

\subsection{Suspended sediment}

To assess sediment transport in the Ameland Inlet system, suspended particle concentrations and turbidity were measured. Turbidity at the distal end of the ebb-tidal delta generally shows an increase in response to energetic conditions (i.e. storms) as well as to calmer conditions near the low water slack (Fig. 7). Pearson et al. (2019) attribute these dif- 


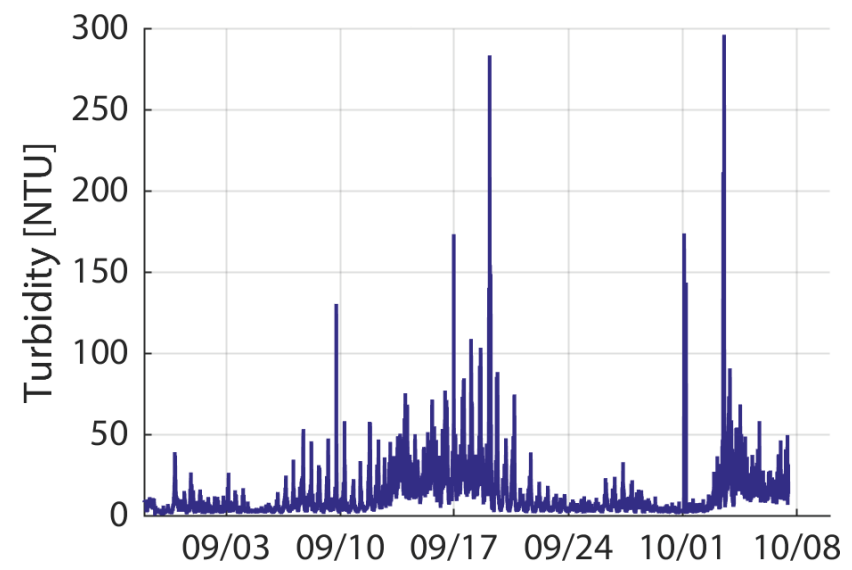

Figure 7. Turbidity measured at AZG Frame 4 ( $8 \mathrm{~m}$ depth) on the ebb-tidal delta using the YSI multiparameter turbidity probe, located $1.3 \mathrm{~m}$ above the seabed. Peaks in turbidity correspond to the two major storms, but in calmer conditions the water can also become turbid at low water slack, when suspended matter is ejected from the Wadden Sea.

ferences to locally resuspended fine sand $\left(d_{50} \simeq 210 \mu \mathrm{m}\right)$ or flocculated fine sediment and organic particles advected from the Wadden Sea.

Measurements of suspended particle size distribution and volumetric concentration $(\mu L / L)$ were also obtained using LISSTs, which showed similar responses to the YSI multiprobe turbidity sensors. OBSs deployed during this campaign were calibrated in the laboratory using sediment obtained from the seabed near the measurement frames. However, due to the different response of optical sensors to sand versus other suspended particles, these calibrations may not be valid where high concentrations of organic matter and flocculated fine sediment were present in the seawater. Further analysis is needed before the OBS measurements from areas with mixed sediments can be used.

\subsection{Bathymetry and bed composition}

The bedforms at one of the multibeam tracks are shown in Fig. 8. Megaripples with a length of $6 \mathrm{~m}$ are found in the channel (Profile 2), while the bedforms at the channel slope are much larger, approximately $20 \mathrm{~m}$ (Profile 1).

Below all frames, small-scale ripples were present throughout the full measurement campaign. They were generally between 2 and $3.5 \mathrm{~cm}$ high, between 8 and $13 \mathrm{~cm}$ long and highly three-dimensional (Fig. 8b).

The $d_{50}$ grain size at the lower shoreface ranges from around $200 \mu \mathrm{m}$ around $12 \mathrm{~m}$ water depth to $230 \mu \mathrm{m}$ (Ameland) and $300 \mu \mathrm{m}$ (Terschelling) at a depth of around $20 \mathrm{~m}$. The subsurface of the lower shoreface at Ameland and Terschelling is mostly sandy, with local clay bands of about $5 \mathrm{~cm}$. The sediments consist of recent marine sands (Southern Bight Formation) on top of Holocene tidal deposits.
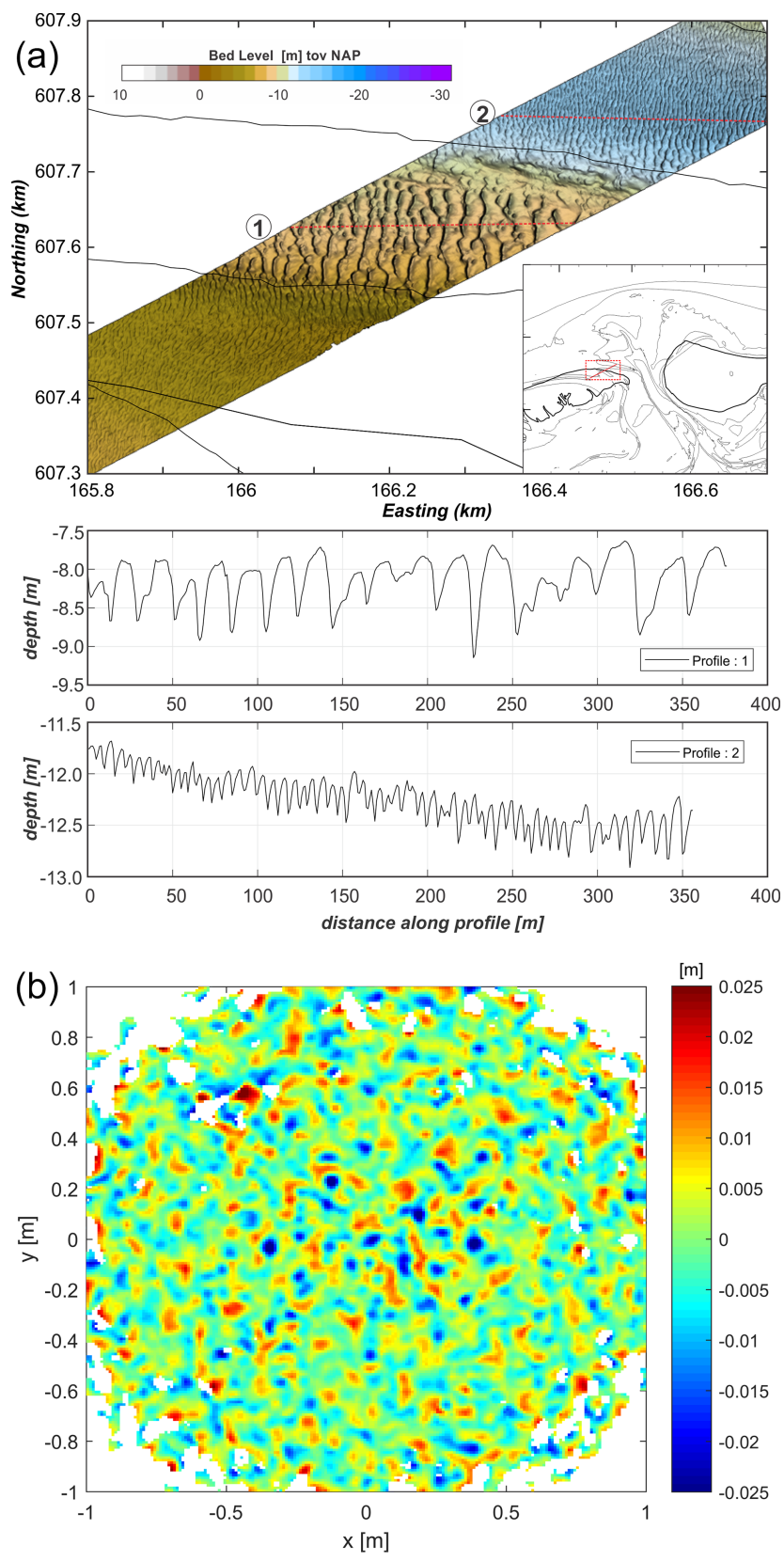

Figure 8. (a) Bed level as measured with multibeam for the band as indicated in lower right subpanel. The bed levels along two transects (as indicated in red with 1 and 2 in the map) are shown below the map. Clear variations in bedforms are visible, related to the larger-scale bathymetry. (b) Relative bed level as measured below the frame with the sonar, indicating small-scale ripples. 


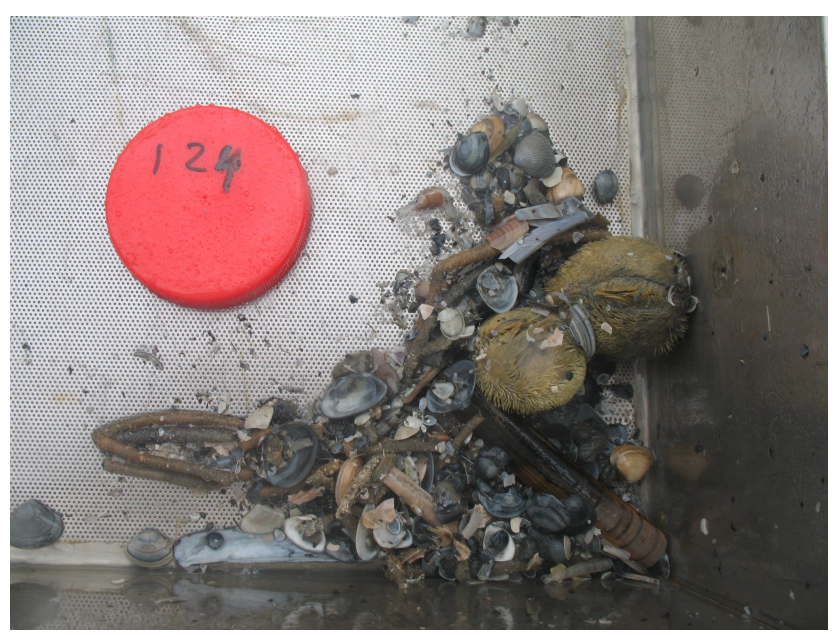

Figure 9. Example of benthos extracted from box core with $1 \mathrm{~mm}$ sieve, showing among others Echinocardium cordatum and Ensis directus.

Deeper cores from the database of the Dutch Geological Survey show Pleistocene sediments of the so-called Eem Formation below the tidal deposits.

In total 71 unique macrobenthic species were found at the ebb-tidal delta, mostly worms, crustaceans, bivalves and echinoderms. On average, nine species per sample location were found.

\section{Data availability}

The data presented in this article have been published at 4TU Centre for Research Data. See https://doi.org/10.4121/collection:seawad (Delft University of Technology et al., 2019) and https://doi.org/10.4121/collection:kustgenese2 (Rijkswaterstaat and Deltares, 2019) following the FAIR principles (Wilkinson et al., 2016). The datasets are published in netCDF format and follow conventions for CF (Climate and Forecast) metadata. The underlying raw data as produced by the instruments together with the scripts for conversion to netCDF with metadata are maintained under version control (subversion). Conversion scripts are written in Python or MATLAB and developed to run platform independent. The metadata in the netCDF files specify the date and version number of underlying raw source data and conversion script in order to provide replicability information. Each collection (SEAWAD or KUSTGENESE2) contains datasets for types of instruments (e.g. "KUSTGENESE2.0/SEAWAD Velocitymeter and Turbidity sensor"). These datasets are subsequently split into directories per area and period (e.g. "2017_09_ameland_azg/", indicating the Amelander Inlet for September 2017). Each directory contains the netCDF files (e.g. adv_azg_201709_F3.nc containing the ADV results for Ameland Inlet for September 2017, for
Frame 3). The data could also be found by searching with the keywords "Ameland and ADV". An interactive map is available, indicating the measurement locations of each dataset.

\section{Conclusions}

A unique and comprehensive dataset is presented, containing bathymetric data, hydrodynamic data, sediment data and benthic species distributions. The data were collected on the ebb-tidal delta of the Ameland Inlet and the lower shoreface offshore Ameland Inlet, Terschelling and Noordwijk, the Netherlands.

This dataset will help increase the understanding of fundamental processes over complex bathymetries under the combined influence of waves, wind and tidal currents.

High-frequency hydrodynamic data were retrieved at several locations over the ebb-tidal delta, channels and lower shoreface. This high-resolution dataset allows the analysis of intra-wave processes in this complex environment, including the influence of the tidal currents on wave transformation (de Wit et al., 2019). The measurement period was sufficiently long to capture several storm events as well as calm conditions. This provides the opportunity to analyse the influence of wind, waves and tidal flow on bed shear stresses, which are important for sediment transport.

The ebb-tidal delta has a complex bathymetry where hydrodynamic processes vary highly in space. The measurements at various locations and the X-band radar data can be used to analyse the spatial variation of flow, waves and sediment transport. The subsequent bathymetric surveys provide information about the morphological feedback resulting from these processes. First steps were taken in Nederhoff et al. (2019) and Reniers et al. (2019) to calibrate numerical models of the area.

The combination of ecological and physical data can be used to develop and verify the (conceptual) models that describe interactions between biotic and abiotic processes.

The data can furthermore be used to improve algorithms for the modelling of the interaction between waves, flow and sediment transport. The high-frequency data are suitable for testing intra-wave-scale models, where the spatial coverage allows comparison with larger-scale wave-resolving models.

These data are used within the joint SEAWAD and KustGenese2.0 programme to analyse the Ameland ebb-tidal delta (ETD) as representative of the other Wadden Sea ebbtidal deltas, as well as the lower shoreface sediment dynamics. Ultimately, the results will be used for designing effective nourishment strategies to let the Dutch coastal zone keep pace with sea level rise.

Author contributions. BCvP was involved in the set-up, coordination and analysis; ZBW was initiator of SEAWAD and KustGenese2.0; MFST, AJHMR and FPdW analysed ADCP-ADV-OBS 
frame data; SGP analysed LISST-MPP frame data and grab samples; TV analysed box cores and vibrocores; MG analysed the Xband radar; PKT and BG were involved in the set-up of the campaign; $\mathrm{HH}$ and CAS planned and carried out the box-coring campaign; LBB and MvdV analysed the sonar data; JvdW coordinated the second and third campaign; EPLE analysed multibeam data; FK and JWM were responsible for the operation of the field campaign; MCGvM took care of preparing the frames; JAAA, PLMdV and GS carried out quality checks and processed data; CdH and RJAW were responsible for data storage on the repository; HdL and CvGM coordinated Kustgenese 2.0.

Competing interests. The authors declare that they have no conflict of interest.

Acknowledgements. The authors would like to thank the crew from the Rijkswaterstaat vessels that made these measurements possible. We highly appreciated the constructive comments and checks of Neil Ganju and Dirk Fleischer.

Financial support. This project is part of the research programme SEAWAD, a "Collaboration Program Water" (project no. 14489), which is financed by the Netherlands Organisation for Scientific Research (NWO) Domain Applied and Engineering Sciences and co-financed by Rijkswaterstaat (Ministry of Infrastructure and Water Management in the Netherlands). The measurement campaign was co-financed by Rijkswaterstaat as well, in the context of the Coastal Genesis 2.0 project. The PhD projects of Laura B. Brakenhoff, Stuart G. Pearson, Floris P. de Wit and Harriette Holzhauer are financed by the SEAWAD project.

Review statement. This paper was edited by Dirk Fleischer and reviewed by Neil Ganju and Dirk Fleischer.

\section{References}

Boothroyd, J. C.: Tidal inlets and tidal deltas, in: Coastal sedimentary environments, pp. 445-532, Springer, New York, NY, 1985.

Bosch, J., Cleveringa, P., and Meijer, T.: The Eemian stage in the Netherlands: history, character and new research, Neth. J. Geosci., 79, 135-145, 2000.

Davis Jr., R. A. and Hayes, M. O.: What is a wave-dominated coast?, Mar. Geol., 60, 313-329, 1984.

De Kruif, A.: Bodemdieptegegevens van Nederlandse kustsysteem: Beschikbare digitale data en een overzicht van aanvullende analoge data, Rapportnr.: 2001.041, Rijksinstituut voor Kust en Zee/RIKZ, Den Haag, 2001.

Delft University of Technology, Utrecht University, and University of Twente: SEAWAD: SEdiment supply At the WAdden Sea ebb-tidal Delta, 4TU Research Data, https://doi.org/10.4121/collection:seawad, 2019.

de Wit, F., Tissier, M., and Reniers, A.: Characterizing wave shape evolution on an ebb-tidal shoal, J. Marine Sci. Eng., 7, 1-20, 2019.
Elgar, S., Raubenheimer, B., and Guza, R.: Quality control of acoustic Doppler velocimeter data in the surfzone, Meas. Sci. Technol., 16, 1889-1893, 2005.

Elias, E., Van der Spek, A., Wang, Z. B., and De Ronde, J.: Morphodynamic development and sediment budget of the Dutch Wadden Sea over the last century, Neth. J. Geosci., 91, 293-310, 2012.

Elias, E. P., Van der Spek, A. J., Pearson, S. G., and Cleveringa, J.: Understanding sediment bypassing processes through analysis of high-frequency observations of Ameland Inlet, the Netherlands, Mar. Geol., 415, 105956, https://doi.org/10.1016/j.margeo.2019.06.001, 2019.

Fraccascia, S., Winter, C., Ernstsen, V. B., and Hebbeln, D.: Residual currents and bedform migration in a natural tidal inlet (Knudedyb, Danish Wadden Sea), Geomorphology, 271, 74-83, 2016.

Friedman, J.: Development of an X-band radar depth inversion model at the sand motor, Master's thesis, TU Delft, 2013.

Gatto, V. M., van Prooijen, B. C., and Wang, Z. B.: Net sediment transport in tidal basins: quantifying the tidal barotropic mechanisms in a unified framework, Ocean Dynam., 67, 1385-1406, 2017.

Glaeser, J. D.: Global distribution of barrier islands in terms of tectonic setting, J. Geol., 86, 283-297, 1978.

Goring, D. G. and Nikora, V. I.: Despiking acoustic Doppler velocimeter data, J. Hydraul. Eng., 128, 117-126, 2002.

Hayes, M. O.: Morphology of sand accumulation in estuaries: an introduction to the symposium, in: Geology and Engineering, Elsevier, 3-22, 1975.

Hayes, M. O. and FitzGerald, D. M.: Origin, evolution, and classification of tidal inlets, J. Coast. Res., 69, 14-33, 2013.

Jarrett, J. T.: Tidal prism-inlet area relationships., Tech. rep., Army Engineer Waterways Experiment Station, Vicksburg Mississippi, 1976.

Mori, N., Suzuki, T., and Kakuno, S.: Noise of acoustic Doppler velocimeter data in bubbly flows, J. Eng. Mech., 133, 122-125, 2007.

Mulder, J. P., Hommes, S., and Horstman, E. M.: Implementation of coastal erosion management in the Netherlands, Ocean Coast. Manage., 54, 888-897, 2011.

Nederhoff, C., Schrijvershof, R., Tonnon, P., Van der Werf, J., and Elias, E.: Modelling Hydrodynamics in the Ameland Inlet as a Basis for Studying Sand Transport, in: International Conference on Coastal Sediments 2019, edited by: Wang, P., Rosati, J., and Vallée, M., V., pp. 1971-1983, World Scientific, 2019.

Pearson, S., Van Prooijen, B., De Wit, F., Meijer-Holzhauer, H., De Looff, A., and Wang, Z.: Observations of Suspended Particle Size Distribution on an Energetic Ebb-Tidal Delta, in: International Conference on Coastal Sediments 2019, edited by: Wang, P., Rosati, J., and M, V., pp. 1991-2003, World Scientific, 2019.

Reniers, A., De Wit, F., Tissier, M., Pearson, S., Brakenhoff, L., Van der Vegt, M., Mol, J., and Van Prooijen, B.: Wave-Skewness and Current-Related Ebb-Tidal Delta Sediment Transport: Observations and Modeling, in: International Conference on Coastal Sediments 2019, edited by: Wang, P., Rosati, J., and Vallée, M., pp. 2018-2028, World Scientific, 2019.

Rijkswaterstaat and Deltares: KUSTGENESE2.0, 4TU Research Data, https://doi.org/10.4121/collection:kustgenese2, 2019.

Ruessink, G., Brinkkemper, J., and Kleinhans, M.: Geometry of wave-formed orbital ripples in coarse sand, J. Mar. Sci. Eng., 3, 1568-1594, 2015. 
Stutz, M. L. and Pilkey, O. H.: Open-ocean barrier islands: global influence of climatic, oceanographic, and depositional settings, J. Coast. Res., 27, 207-222, 2011.

Van Rijn, L. C.: Sediment transport and budget of the central coastal zone of Holland, Coastal Eng., 32, 61-90, 1997.

van Veen, J., Van Der SPEK, A. J., Stive, M. J., and Zitman, T.: Ebb and flood channel systems in the Netherlands tidal waters, J. Coast. Res., 21, 1107-1120, 2005.

Wang, Z. B., Elias, E. P., van der Spek, A. J., and Lodder, Q. J.: Sediment budget and morphological development of the Dutch Wadden Sea: impact of accelerated sea-level rise and subsidence until 2100, Neth. J. Geosci., 97, 183-214, 2018.
Wilkinson, M. D., Dumontier, M., Aalbersberg, I. J., Appleton, G., Axton, M., Baak, A., Blomberg, N., Boiten, J.-W., Bonino da Silva Santos, L., Bourne, P. E., Bouwman, J., Brookes, A. J., Clark, T., Crosas, M., Dillo, I., Dumon, O., Edmunds, S., Evelo, C. T., Finkers, R., Gonzalez-Beltran, A., Gray, A. J. G., Groth, P., Goble, C., Grethe, J. S., Heringa, J., 't Hoen, P. A. C., Hooft, R., Kuhn, T., Kok, R., Kok, J., Lusher, S. J., Martone, M. E., Mons, A., Packer, A. L., Persson, B., Rocca-Serra, P., Roos, M., van Schaik, R., Sansone, S.-A., Schultes, E., Sengstag, T., Slater, T., Strawn, G., Swertz, M. A., Thompson, M., van der Lei, J., van Mulligen,' E., Velterop, J., Waagmeester, A., Wittenburg, P., Wolstencroft, K., Zhao, J., and Mons, B.: The FAIR Guiding Principles for scientific data management and stewardship, Sci. Data, 3, 1-9, 2016. 